\title{
Abroma augusta L. (Malvaceae) leaf extract attenuates diabetes induced nephropathy and cardiomyopathy via inhibition of oxidative stress and inflammatory response
}

Ritu Khanra ${ }^{1 \dagger}$, Saikat Dewanjee ${ }^{1 \dagger}$, Tarun K Dua ${ }^{1}$, Ranabir Sahu', Moumita Gangopadhyay ${ }^{2}$, Vincenzo De Feo ${ }^{3^{*}}$ and Muhammad Zia-Ul-Haq ${ }^{4^{*}}$

\begin{abstract}
Background: Abroma augusta L. (Malvaceae) leaf is traditionally used to treat diabetes in India and Southern Asia. Therefore, current study was performed to evaluate the protective effect of defatted methanol extract of $A$. augusta leaves (AA) against type 2 diabetes mellitus (T2DM) and its associated nephropathy and cardiomyopathy in experimental rats.

Methods: Antidiabetic activity of AA extracts (100 and $200 \mathrm{mg} / \mathrm{kg}$, p.o.) was measured in streptozotocin-nicotinamide induced type 2 diabetic (T2D) rat. Fasting blood glucose level (at specific interval) and serum biochemical markers (after sacrifice) were measured. Redox status, transcription levels of signal proteins (NF-KB and PKCs), mitochondria dependent apoptotic pathway (Bad, Bcl-2, caspase cascade) and histological studies were performed in kidneys and hearts of controls and AA treated diabetic rats.

Results: Phytochemical screening of extracts revealed the presence of taraxerol, flavonoids and phenolic compounds in the AA. T2D rats showed significantly $(p<0.01)$ elevated fasting blood glucose level. Alteration in serum lipid profile and release of membrane bound enzymes like lactate dehydrogenase and creatine kinase, which ensured the participation of hyperlipidemia and cell membrane disintegration in diabetic pathophysiology. T2DM caused alteration in the serum biochemical markers related to diabetic complications. T2DM altered the redox status, decreased the intracellular NAD and ATP concentrations in renal and myocardial tissues of experimental rats. Investigating the molecular mechanism, activation PKC isoforms was observed in the selected tissues. T2D rats also exhibited an up-regulation of NF-KB and increase in the concentrations of pro-inflammatory cytokines (IL-1 $\beta, I L-6$ and TNF- $\alpha$ ) in the renal and cardiac tissues. The activation of mitochondria dependent apoptotic pathway was observed in renal and myocardial tissues of the T2D rats. However, Oral administration of AA at the doses of 100 and $200 \mathrm{mg} / \mathrm{kg}$ body weight per day could reduce hyperglycemia, hyperlipidemia, membrane disintegration, oxidative stress, vascular inflammation and prevented the activation of oxidative stress induced signaling cascades leading to cell death. Histological studies also supported the protective characteristics of AA.
\end{abstract}

Conclusions: Results suggest that AA could offer prophylactic role against T2DM and its associated reno- and cardio- toxicity.

Keywords: Abroma augusta, Cardiomyopathy, Nephropathy, Oxidative stress, Streptozotocin-nicotinamide, Type 2 diabetes mellitus

\footnotetext{
*Correspondence: defeo@unisa.it; ahirzia@gmail.com

${ }^{\dagger}$ Equal contributors

${ }^{3}$ Department of Pharmacy, University of Salerno, Fisciano, Salerno 84084, Italy

${ }^{4}$ Office of Research, Innovation and Commercialization, Lahore College for

Women University, Lahore 54600, Pakistan

Full list of author information is available at the end of the article
} 


\section{Introduction}

Diabetes mellitus (DM) is a chronic metabolic disorder characterized by hyperglycemia which may be due to unusual discharge of insulin and/or resistance to insulin. The disease has a significant effect on social, psychological as well as physical quality of life [1]. Approximately 366 million people are suffering from DM around the world and the incidence of this disease is predicted to be more than double by the year of 2030 [2]. Non-insulin dependent or Type 2 DM (T2DM) is most prevalent among various types of DM, which comprises 90-95\% of all diagnosed cases of DM [3]. The persistent hyperglycemia is accountable for the damages of various organs and tissues in diabetic patients. However, diabetic complications are not merely due to hyperglycemia. Previous investigations have indicated that oxidative stress is a key factor in etiology of diabetic complications like cardiomyopathy and nephropathy $[4,5]$. However, the exact source of oxidative free radicals is yet to be recognized. Mitochondrial dysfunction, advanced glycation end processes and others are believed to be the probable sources [6]. Generation of oxidative free radicals results in oxidative disruption of structural proteins and degradation of membrane-bound-phospholipids. Moreover, reactive free radicals cause fragmentation of DNA, which results apoptotic cell death [7]. Oxidative stress also leads to impairment of endogenous antioxidant enzymes due to their non-enzymatic glycosylation and auto-oxidation [8]. These super-active radicals may also disturb the expressions of several transcription proteins like NF- $\mathrm{KB}$, PKCs, caspases etc. [4]. It is well-known that inflammatory cytokines viz. TNF- $\alpha$, IL- 6 and IL- $1 \beta$ play key roles in the cascade of inflammation and systemic insulin resistance and thereby participate directly in diabetic nephropathy and cadiomyopathy [4]. Therefore, it is important to counteract diabetic pathophysiology through multi-target therapeutic agent. Multi-component plant extract (chemically standardized) could offer this multimodal therapeutic value.

Abroma augusta L. (Malvaceae), an evergreen shrub, is found throughout the hot and humid parts of India. Leaves and seeds of $A$. augusta are considered to be edible in India and New Guinea. A. augusta has an allembracing history in Ayurvedic system. Leaves are used as a remedy for diabetes, inflammation, rheumatic pain of joints, uterine disorders, and headache [9-11]. The whole plant contains alkaloids, steroids, triterpenes, flavonoids, megastigmanes, and phenylethanoid glycosides [12]. Since the selected plant species was claimed to possess both anti-diabetic and anti-inflammatory activities, the present investigation was performed to evaluate the protective effect of $A$. augusta leaves on T2DM and its associated pathogenesis in renal and cardiac tissues. Streptozotocin-nicotinamide induced T2DM model on experimental rats was chosen for this study. The effect of test drug on fasting blood glucose level, serum lipid profile and other biochemical markers associated with diabetic pathogenesis was investigated. The protective effect of A. augusta leaves on oxidative stress and inflammation mediated pathogenesis was investigated and mechanism by which AA exerts its protective effect was evaluated by estimating the transcription levels of signal proteins. Finally, histopathological studies of kidney and heart were performed to confirm the protective effect of $A$. augusta leaves.

\section{Material and methods \\ Preparation of extract}

Mature leaves of $A$. augusta were collected from Howrah district, West Bengal, India in May, 2013. The plant material was authenticated (Ref no. CNH/45/2013/Tech.II/ 1070) by Dr. V. P. Parsad, Taxonomist, Central National Herbarium, Botanical Survey of India, Shibpur, India. A voucher specimen JU/PT/PC/04/2013 was submitted at Advanced Pharmacognosy Research Laboratory, Department of Pharmaceutical Technology, Jadavpur University, India. The dried powdered leaves $(2.5 \mathrm{~kg})$ were macerated with $\mathrm{MeOH}(4 \times 10 \mathrm{l})$ with continuous agitation. The $\mathrm{MeOH}$ extract ( $312 \mathrm{~g}$, yield $\approx 12.5 \% \mathrm{w} / \mathrm{w}$ ) was dissolved in $\mathrm{Et}_{2} \mathrm{O}\left(30^{\circ} \mathrm{C}\right)$ for removal of fat and waxes. The residue (AA, $210 \mathrm{~g}$ ) was subjected in this study.

\section{Phytochemical analysis}

Preliminary phytochemical analysis (TLC studies followed by spraying the chromatogram with specific reagents) revealed presence of triterpenoids, steroids, flavonoids and phenolic compounds in AA. Based on the preliminary phytochemical studies, AA was subjected further for detailed phytochemical profiling. AA (100 g) was extracted with $\mathrm{CH}_{2} \mathrm{Cl}_{2}(5 \times 3 \mathrm{l})$ to yielding $26 \mathrm{~g}$ of $\mathrm{CH}_{2} \mathrm{Cl}_{2}$ soluble fractions which was enriched with steroids and triterpenoids. $\mathrm{CH}_{2} \mathrm{Cl}_{2}$ fractions were subjected to silica gel-column chromatography using mixtures of $n$-hexaneEtOAc and EtOAc-MeOH of increasing polarity to yield fractions (A-F). Fraction A (0.38 g) was chromatographed with n-hexane- $\mathrm{CH}_{2} \mathrm{Cl}_{2}$ and $\mathrm{CH}_{2} \mathrm{Cl}_{2}-\mathrm{MeOH}$, to yield compound 1 (12 mg). Fraction $\mathrm{B}(2.5 \mathrm{~g})$ was chromatographed with n-hexane- $\mathrm{CH}_{2} \mathrm{Cl}_{2}$ and $\mathrm{CH}_{2} \mathrm{Cl}_{2}-\mathrm{MeOH}$ to yield compound $2(72 \mathrm{mg})$. Fraction $\mathrm{C}(0.65 \mathrm{~g})$ and fraction $\mathrm{D}$ $(0.32 \mathrm{~g})$ also yielded compound 2 of 25 and $11 \mathrm{mg}$, respectively. Fraction $\mathrm{E}$ (10.5) was chromatographed with nhexane- $\mathrm{CH}_{2} \mathrm{Cl}_{2}$ and $\mathrm{CH}_{2} \mathrm{Cl}_{2}-\mathrm{MeOH}$ to yield compound 3 (24 mg). RP-HPLC analysis of AA was performed to detect presence of phenolics and flavonoids by comparing with reference phytochemical markers. Chromatographic studies were performed by HPLC (Dionex Ultimate 3000, Germany), having a UV detector and a C-18 RP column $(250 \times 4.6 \mathrm{~mm}$, particle size 51$)$. The samples were 
dissolved in HPLC-grade methanol and filtered from a $0.45 \mu \mathrm{m}$ nylon membrane filter (Pall Life Science, USA). The aliquots of the filtrate were eluted with isocratic solvent mixture comprising methanol:acetonitrile:acetic acid: o-phosphoric acid: water (20:10:1:1:20) for flavonoids and methanol:water:acetic acid (25:74:1) for phenolic compounds with flow rate of $1 \mathrm{ml} \mathrm{min}{ }^{-1}$ and detected at 340 and $254 \mathrm{~nm}$ respectively.

\section{Animals}

Animal models comprised of male Wistar rats (weight $180 \pm 20$ g; age 2-3 months). The rats were housed in standard polyprophylene cages under standard lab conditions of $12 \mathrm{~h}$ light-dark cycle, temperature $\left(20 \pm 2^{\circ} \mathrm{C}\right)$, relative humidity $(50 \pm 15 \%)$, standard diet and water ad libitum. The animal experiments were pursued at the Department of Pharmaceutical Technology, Jadavpur University, India (CPCSEA Reg. No. 0367/01/C/CPCSEA). The institutional animal ethical committee instructions as well as principles of laboratory animals care [13] were followed throughout experiment.

\section{Oral Glucose Tolerance Test (OGTT)}

Overnight fasted male Wistar rats were divided into 3 groups of 6 rats each. OGTT was performed by treating the animals with glucose $(1.5 \mathrm{~g} / \mathrm{kg}$, p.o.) [14]. Just after glucose feeding, two groups of rats were fed with AA (100, $200 \mathrm{mg} / \mathrm{kg}$, p.o., respectively). A group of animals were treated with double distilled water $(2 \mathrm{ml} / \mathrm{kg}$, p.o.) and kept as control. Blood glucose levels were measured at $0,30,60$, and $120 \mathrm{~min}$ after glucose treatment with the help of single touch glucometer (Ascensia Entrust, Bayer Health Care, USA). Total glycaemic responses were calculated from respective areas under the curve (AUC) during the $120 \mathrm{~min}$ of observation period.

\section{Comparison between streptozotocin and streptozotocin- nicotinamide model}

Overnight fasted male Wistar rats were divided into 3 groups of 6 rats each. One group of animals received single intraperitonial injection (i.p.) of streptozotocin $(65 \mathrm{mg} / \mathrm{kg})$ in citrate buffer $(\mathrm{pH} 4.5)$. The other group of rats were treated with nicotinamide $(110 \mathrm{mg} / \mathrm{kg}$, i.p.) followed by (after $15 \mathrm{~min}$ ) streptozotocin $(65 \mathrm{mg} / \mathrm{kg}$, i.p.) in citrate buffer ( $\mathrm{pH} 4.5)$ [15]. One group of rats without treatment served as control. After 1 week, animals were subjected to fasting blood glucose level and insulin level measurements. Fasting blood serum glucose level was measured by single touch glucometer (Ascensia Entrust, Bayer Health Care, USA). Serum insulin was also measured by kits (Span Diagnostics Ltd., Surat, India) following manufacturer protocol.

\section{Induction of T2DM and experimental design}

T2DM was induced in overnight fasted rats by a single intraperitoneal injection (i. p.) of streptozotocin $(65 \mathrm{mg} / \mathrm{kg})$ in citrate buffer ( $\mathrm{pH} 4.5), 15$ min later the administration of nicotinamide $(110 \mathrm{mg} / \mathrm{kg}$, i. p.) [15]. After 1 week, animals exhibiting fasting glucose levels between 140$200 \mathrm{mg} / \mathrm{dl}$ were screened as type 2 diabetic (T2D) rats and were used for the antidiabetic assay. Animals were divided into 5 groups of 6 rats each as follows:

Gr I: Normal rats were given double distilled water (2 ml/kg, p.o.) daily for 4 weeks;

Gr II: T2D control rats were given distilled water

( $2 \mathrm{ml} / \mathrm{kg}$, p.o.) daily for 4 weeks;

Gr III: T2D rats were given AA (100 mg/kg, p.o.) daily

for 4 weeks;

Gr IV: T2D diabetic rats were given AA (200 mg/kg,

p.o.) daily for 4 weeks;

Gr V: T2D rats were given standard drug glibenclamide (1 mg/kg, p.o.) [5] daily for 4 weeks.

\section{Serum biochemical analysis}

Single touch glucometer (Ascensia Entrust, Bayer Health Care, USA) was utilized to estimate fasting blood glucose level on day $0,1,3,7,14,21$ and 28. For estimation of serum biochemical parameters, eppendroff tubes rinsed with anticoagulants were used for collection of blood samples after 28 days. From this blood, serum was separated by centrifugation at $3000 \mathrm{~g}$ for $10 \mathrm{~min}$ [5]. Enzymatic colorimetric kits (Span Diagnostics Ltd., Surat, India) were used for determination of serum triglyceride and cholesterol profiles while serum insulin was measured by kits (Span Diagnostics Ltd., Surat, India) following manufacturers protocols. Glycosylated hemoglobin was estimated according to method of Nayak and Pattabiraman [16]. Lipid profile (total cholesterol, HDL cholesterol, and triglyceride), alanine aminotransferase (ALT) and aspartate aminotransferase (AST), urea and the membrane leakage enzymes (creatine kinase and lactate dehydrogenase) were assessed by standard kits (Span Diagnostic Limited, India) following manufacturer protocol.

\section{Organs' biochemical analysis}

The rats were anesthetized and sacrificed by cervical dislocation after 28 days. The organs (heart and kidney) were excised, cleaned and washed with ice-cold saline ( $\mathrm{pH} 7.4)$. The organs were homogenized in Tris- $\mathrm{HCl}(0.1 \mathrm{M})$ EDTA buffer $(\mathrm{pH} 7.4,0.001 \mathrm{M})$ and centrifuged at $12,000 \mathrm{~g}$ for $30 \mathrm{~min}$ at $4^{\circ} \mathrm{C}$. Biochemical parameters were assessed from collected supernatant. The intracellular reactive oxygen species (ROS) production was measured by the method of LeBel and Bondy [17] with a minor modification introduced by Kim et al. [18]. Fluorescence spectrometer (Hitachi, F4500) set at excitation wavelength of 
$488 \mathrm{~nm}$ and emission wavelength of $510 \mathrm{~nm}$ was used for measurement of 2', 7'dichloro-fluorescein (DCF) formation. The extent of lipid peroxidation was measured by evaluating thiobarbituric cid reactive substances (TBARS) following the protocol of Ohkawa et al. [19]. Protein carbonylation was estimated by method of Uchida and Stadtman [20]. Co-enzymes $\mathrm{Q}\left(\mathrm{Q}_{9}\right.$ and $\left.\mathrm{Q}_{10}\right)$ were isolated and estimated according to the method of Zhang et al. [21]. Reduced glutathione (GSH) level was measured by Hissin and Hilf's method [22]. Activity of antioxidant enzymes like catalase (CAT), superoxide dismutase (SOD), glutathione peroxidase (GPx), glutathione-6-phosphate dehydrogenase (G6PD) and glutathione reductase (GR) was estimated by the methods reported by Ghosh et al. [23]. Homogenates were screened for NAD by colometric method [24] while intracellular ATP concentrations were assessed by commercial kits (Abcam, Cambridge, USA) following manufacturer protocol.

\section{Immunoblotting}

SDS-PAGE (10\%) was used for separation of proteins from $20 \mu \mathrm{g}$ protein sample and transferred into nitrocellulose membrane. These membranes were blocked (blocking buffer containing $5 \%$ non-fat dry milk) for $1 \mathrm{~h}$ at room temperature and later incubated with primary antibodies (anti-rat antibodies produced in rabbit) viz. anti-Bcl-2 (1:500), anti-Bax (1:500), anti-caspase 3 (1:1000), antiPKC- $\alpha$ (1:500), anti-PKC- $\beta$ (1:500), anti-PKC- $\delta$ (1:500), anti-PKC- $\varepsilon$ (1:500), anti-NF-кB (1:1000), and anti- $\beta$-actin (1:1000) antibodies at $4^{\circ} \mathrm{C}$ overnight. Tris-Buffered Saline with $0.1 \%$ Tween $20(\mathrm{pH} 7.6)$ was used for washing of membranes for $15 \mathrm{~min}$, incubated with appropriate HRP conjugated secondary antibody (anti-rabbit antibodies produced in goat) at 1:2000 dilutions at room temperature for $2 \mathrm{~h}$ and developed by HRP substrate 3, 3'- diaminobenzidine tetrahydrochloride system (Banglore genei, India).

\section{Assay of inflammatory cytokines}

Concentrations of inflammatory cytokines (IL-1 $\beta$, IL-6, TNF- $\alpha$ ) in cardiac and renal tissue samples were analyzed by ELISA. A labsystem integrated EIA Management System iEMS and Delta Soft 32.22 EMS software was used for measurement of optical density.

\section{Histological studies}

Isolated organs from normal and experimental rats were fixed in buffered formalin (10\%) and processed for paraffin sectioning. Sections obtained (approx. $5 \mu \mathrm{m}$ ) were stained by hematoxylin and eosin to study the histology of isolated organs [25].

\section{Statistical analysis}

One-way ANOVA was utilized for statistical analysis of data and expressed as mean \pm SE followed by Dunnett's $t$-test using computerized GraphPad InStat (version 3.05), GraphPad software, USA. The values were considered significant when $p<0.05$.

\section{Results and discussion \\ Phytochemical analysis}

The structures of isolated compounds were characterized by analyzing NMR and mass spectrometric data. Compound 1, 2 and 3 were identified as taraxerone, taraxerol and stigmasterol (Additional file 1: Figure S1). The phenolic and flavonoid compound were identified by RP-HPLC and comparing retention time $\left(\mathrm{R}_{\mathrm{t}}\right)$ and UV spectra with standard marker compounds. HPLC analysis revealed presence of flavonoids viz. rutin $\left(22.4 \mathrm{mg} \mathrm{g}^{-1 \mathrm{DW}}, \mathrm{R}_{\mathrm{t}}: 3.0\right)$, myricetin (14.1 mg g-1DW, $\mathrm{R}_{\mathrm{t}}$ : 3.9), quercetin (19.8 mg $\mathrm{g}^{-1 \mathrm{DW}}, \mathrm{R}_{\mathrm{t}}$ : 5.6) and apigenin (19.2 $\left.\mathrm{mg} \mathrm{g}^{-1 \mathrm{DW}}, \mathrm{R}_{\mathrm{t}}: 8.1\right)$ (Additional file 1: Figure S2), the phenolic compounds viz. gallic acid (17.2 $\left.\mathrm{mg} \mathrm{g}^{-1 \mathrm{DW}}, \mathrm{R}_{\mathrm{t}}: 4.03\right)$ and chlorogenic acid (19.1 $\mathrm{mg} \mathrm{g}^{-1 \mathrm{DW}}, \mathrm{R}_{\mathrm{t}}$ : 7.24) in AA (Additional file 1: Figure S3).

\section{Effect on OGTT}

With the intent to assess the effect of AA on systemic glucose homeostasis, OGTT was performed (Figure 1A). The OGTT study revealed that, oral administration of AA $(100,200 \mathrm{mg} / \mathrm{kg})$ significantly $(\mathrm{p}<0.05-0.01)$ reduced blood glucose concentrations between 30-60 min after glucose $(1.5 \mathrm{mg} / \mathrm{kg})$ load. The AA also exerted a significant influence on total glycaemic response evidenced by the significant reduction of AUC as compared with control group during an OGTT (Figure 1B).

\section{Effect of streptozotocin (singly) and streptozotocin in combination with nicotinamide}

In this study, the effect of streptozotocin (singly) and streptozotocin in combination with nicotinamide was compared (Figure 1C). Both treatments offered a significant elevation of fasting blood glucose level $(p<0.01)$ with concomitant depletion $(\mathrm{p}<0.01)$ of serum insulin level, when compared with normal rats. However, a single intraperitoneal injection (i.p.) of streptozotocin (65 mg/ $\mathrm{kg}$ ) caused nearly complete destruction of $\beta$-cells of pancreas resulting an elevated fasting blood glucose level $\left(\sim 270-360 \mathrm{mg} \mathrm{dl}^{-1}\right)$ with a sharp depletion of insulin level $\left(\sim 0.6 \mu \mathrm{g} \mathrm{dl}^{-1}\right)$. On other hand, the rats exposed to nicotinamide prior to streptozotocin exhibited a blood glucose level ranging between $\sim 160-200 \mathrm{mg} \mathrm{dl}^{-1}$ and insulin level of $\sim 1.8 \mu \mathrm{g} \mathrm{dl}^{-1}$ after day 7 . The statistical comparison between streptozotocin and streptozotocin-nicotinamide treated group revealed a significant difference between fasting blood glucose $(\mathrm{p}<0.05)$ and serum insulin $(\mathrm{p}<0.01)$ levels. The experimental outcome would refer that nicotinamide offers a partial protection against $\beta$-cytoxic effect of streptozotocin [15]. Masiello et al. [15] claimed that 

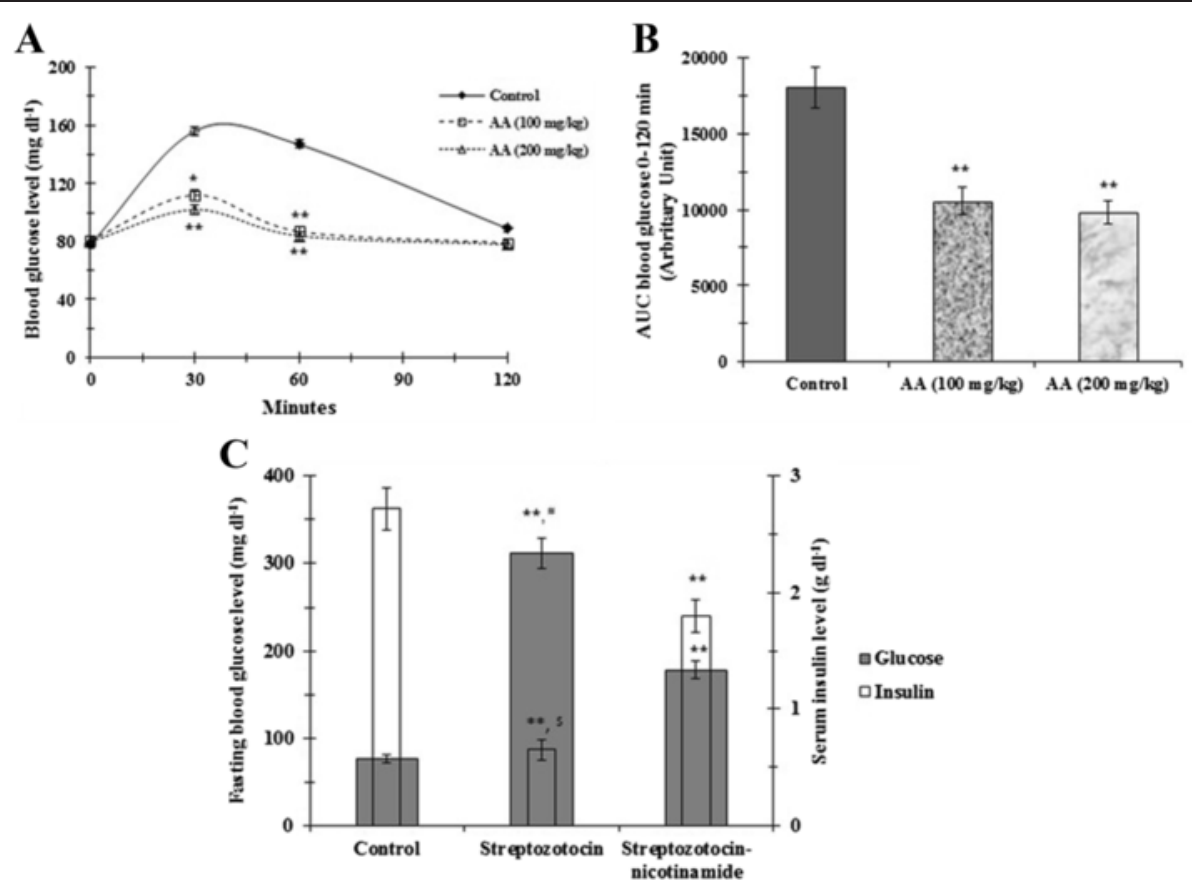

Figure 1 Effect of AA on oral glucose tolerance test (A); the areas under the curve (AUC) were calculated using the trapezoid method (B); comparison between the effects of streptozotocin (singly) and streptozotocin-nicotinamide (in combination) on adult rats (C). Data were expressed as mean $\pm \mathrm{SE}(n=6) .{ }^{*} p<0.05$ compared with control group. ${ }^{* *} p<0.01$ compared with control group. ${ }^{*} p<0.05$ compared with streptozotocin-nicotinamide treated rats. ${ }^{\$} p<0.01$ compared with streptozotocin-nicotinamide treated.

pretreatment of nicotinamide offered $\sim 40 \%$ preservation of pancreatic insulin stores and developed T2DM in adult rats. Therefore, streptozotocin-nicotinamide model has been chosen for this study to evaluate oral hypoglycemic effect of AA.

\section{Effect on fasting blood glucose level and serum biochemical parameters}

A significantly $(\mathrm{p}<0.01)$ high fasting blood glucose level $(170-190 \mathrm{mg} / \mathrm{dl})$ was observed in T2DM rats. Maintenance of blood glucose level within normal range is a primary approach during T2DM treatment. AA (100 and $200 \mathrm{mg} / \mathrm{kg}$ ) treatment could significantly reduce fasting blood glucose level in T2D rat with maximum reduction of $\sim 32.2 \%(\mathrm{p}<0.01)$ and $\sim 40.5 \%(\mathrm{p}<0.01)$ on day 28 , respectively. The standard drug glibenclamide $(1 \mathrm{mg} / \mathrm{kg})$ exhibited maximum reduction of $\sim 48.3 \%(\mathrm{p}<0.01)$ on day 28 (Table 1). Biological effects of AA on serum biochemical parameter were shown in Table 2. T2DM is associated with hyperlipidemia [26]. Investing the lipid profile, significantly $(\mathrm{p}<0.01)$ high levels of total cholesterol, triglycerides with concomitant low HDL cholesterol $(\mathrm{p}<0.01)$ level were observed in the T2D rats, which could suggest the association between hyperglycemia and hyperlipidemia. A significant $(\mathrm{p}<0.01)$ reduction of serum insulin content was observed in T2D rats. It is well-recognized that lipo-protein lipase is activated by insulin which hydrolyzes triglycerides under normal

Table 1 Effect of AA on fasting blood glucose level of T2D rats

\begin{tabular}{|c|c|c|c|c|c|c|c|}
\hline \multirow[t]{2}{*}{ Groups } & \multicolumn{7}{|c|}{ Fasting blood glucose level $\left(\mathrm{mg} \mathrm{dl}^{-1}\right)$ in days } \\
\hline & 0 & 1 & 3 & 7 & 14 & 21 & 28 \\
\hline GrI & $76.48 \pm 3.74$ & $76.04 \pm 4.08$ & $76.21 \pm 3.99$ & $75.84 \pm 3.62$ & $75.63 \pm 2.63$ & $77.22 \pm 2.87$ & $76.43 \pm 3.12$ \\
\hline Gr $॥$ & $171.90 \pm 6.99^{\#}$ & $172.28 \pm 6.91^{\#}$ & $177.44 \pm 7.45$ & $180.77 \pm 6.82^{\#}$ & $184.13 \pm 7.26^{\#}$ & $187.15 \pm 6.15^{\#}$ & $190.47 \pm 6.03^{\#}$ \\
\hline Gr III & $170.63 \pm 9.02^{\#}$ & $168.08 \pm 8.76^{\#}$ & $146.33 \pm 9.77^{*}$ & $142.64 \pm 9.38^{* *}$ & $138.88 \pm 4.08^{* *}$ & $133.27 \pm 3.04^{* *}$ & $129.10 \pm 3.39^{* *}$ \\
\hline Gr IV & $173.22 \pm 5.46^{\#}$ & $165.67 \pm 7.39^{\#}$ & $142.40 \pm 5.64^{* *}$ & $136.08 \pm 6.56^{* *}$ & $126.64 \pm 4.82^{* *}$ & $121.47 \pm 5.27^{* *}$ & $113.39 \pm 4.70^{* *}$ \\
\hline Gr V & $175.32 \pm 7.94^{\#}$ & $168.88 \pm 8.85^{\#}$ & $138.84 \pm 5.59^{* *}$ & $125.71 \pm 5.75^{* *}$ & $113.16 \pm 4.49^{* *}$ & $108.45 \pm 3.73^{* *}$ & $98.40 \pm 2.83^{* *}$ \\
\hline
\end{tabular}

Data were expressed as mean $\pm \mathrm{SE}(\mathrm{n}=6) .{ }^{\#} p<0.01$ compared with normal control group. ${ }^{*} p<0.05$ compared with diabetic control group. ${ }^{* *} p<0.01$ compared with diabetic control group. Gr I: Normal; Gr I: Normal; Gr II: T2D control, Gr III: T2D + AA (100 mg/kg, p.o.); Gr IV: T2D + AA (200 mg/kg, p.o.); Gr V: T2D + glibenclamide (1 mg/kg, p.o.). 
Table 2 Effect of AA on serum biochemical parameters of T2D rats

\begin{tabular}{|c|c|c|c|c|c|}
\hline Parameters & Gr I & Gr II & Gr III & Gr IV & Gr V \\
\hline Total cholesterol $\left(\mathrm{mg} \mathrm{dl}^{-1}\right)$ & $87.12 \pm 3.60$ & $131.32 \pm 3.73^{\#}$ & $104.22 \pm 5.02^{*}$ & $97.53 \pm 3.70^{* *}$ & $94.43 \pm 3.67^{* *}$ \\
\hline HDL-cholesterol (mg dl ${ }^{-1}$ ) & $33.10 \pm 2.94$ & $18.14 \pm 1.13^{\#}$ & $24.61 \pm 2.41$ & $28.98 \pm 3.60^{*}$ & $31.38 \pm 3.17^{* *}$ \\
\hline Triglycerides $\left(\mathrm{mg} \mathrm{dl}^{-1}\right)$ & $76.27 \pm 3.78$ & $123.08 \pm 6.13^{\#}$ & $104.22 \pm 5.67$ & $96.40 \pm 7.10^{*}$ & $82.62 \pm 5.60^{* *}$ \\
\hline Insulin $\left(\mu \mathrm{g} \mathrm{dl}^{-1}\right)$ & $2.68 \pm 0.18$ & $1.64 \pm 0.14^{\#}$ & $2.02 \pm 0.11$ & $2.17 \pm 0.10^{*}$ & $2.23 \pm 0.14^{*}$ \\
\hline Glycosylated haemoglobin ( $\mathrm{mg} \mathrm{g}^{-1}$ haemoglobin) & $0.27 \pm 0.45$ & $0.67 \pm 0.62^{\#}$ & $0.49 \pm 0.73$ & $0.42 \pm 0.65^{*}$ & $0.39 \pm 0.33^{* *}$ \\
\hline $\operatorname{ALT}\left(\mid \mathrm{U} \mathrm{I}^{-1}\right)$ & $69.83 \pm 4.16$ & $101.43 \pm 7.49^{\#}$ & $84.55 \pm 6.35$ & $79.33 \pm 5.13^{*}$ & $73.98 \pm 6.13^{*}$ \\
\hline AST $\left(\left.I U\right|^{-1}\right)$ & $45.32 \pm 4.09$ & $71.69 \pm 4.47^{\#}$ & $58.91 \pm 5.38$ & $54.69 \pm 6.81$ & $51.20 \pm 6.34^{*}$ \\
\hline Urea $\left(\mathrm{mg} \mathrm{dl^{-1 }}\right)$ & $30.63 \pm 2.41$ & $65.04 \pm 4.99^{\#}$ & $46.56 \pm 3.88^{* *}$ & $44.76 \pm 3.07^{* *}$ & $41.86 \pm 3.52^{* *}$ \\
\hline Lactate dehydrogenase $\left(\mathrm{U} \mathrm{I}^{-1}\right)$ & $207.52 \pm 9.36$ & $294.04 \pm 15.24^{\#}$ & $253.75 \pm 15.68$ & $242.82 \pm 13.10^{*}$ & $238.33 \pm 9.98^{*}$ \\
\hline Creatinine kinase (IU mg ${ }^{-1}$ protein) & $4.73 \pm 0.38$ & $8.21 \pm 0.50^{\#}$ & $6.54 \pm 0.57$ & $6.12 \pm 0.39^{*}$ & $5.76 \pm 0.45^{* *}$ \\
\hline C-reactive protein $\left(\mathrm{mg} \mathrm{dl}^{-1}\right)$ & $1.02 \pm 0.10$ & $3.24 \pm 0.24^{\#}$ & $2.18 \pm 0.24^{*}$ & $2.09 \pm 0.32^{* *}$ & $1.61 \pm 0.19^{* *}$ \\
\hline
\end{tabular}

Data were expressed as mean \pm SE $(n=6) .{ }^{\#} p<0.01$ compared with normal control group. ${ }^{*} p<0.05$ compared with diabetic control group.

${ }^{* *} p<0.01$ compared with diabetic control group. Gr I: Normal; Gr I: Normal; Gr II: T2D control, Gr III: T2D + AA (100 mg/kg, p.o.); Gr IV: T2D + AA (200 mg/kg, p.o.); Gr V: T2D + glibenclamide (1 mg/kg, p.o.).

physiological conditions [5]. Therefore, impairment of insulin secretion and/or responsiveness could be the cause of hyperlipidemia in T2DM. However, AA could significantly reinstate the serum lipids $(\mathrm{p}<0.05-0.01)$ and insulin $(\mathrm{p}<0.05)$ levels near to the normalcy. The experimental observation could suggest that AA exerts antihyperglycemic and anti-hyperlipidemic effects through promoting insulin secretion. The increase in blood glucose level is responsible for the increased glycosylation of a number of proteins including haemoglobin [4,27]. In this study, T2DM rats exhibited a significantly $(\mathrm{p}<0.01)$ elevated glycosylated-haemoglobin level. AA (200 mg/kg) treatment could significantly $(\mathrm{p}<0.05)$ reverted the glycosylated-haemoglobin level near to the normal status. A reduction of glycosylation of haemoglobin is accountable to the anti-hyperglycemic effect of AA. Type 2 diabetic rats exhibited significantly $(\mathrm{p}<0.01)$ increased levels of serum AST, ALT and urea as compared with normal control group. An increase in ALT and AST levels in blood may indicate degenerative and necrotic changes in livers (not included in this manuscript), kidneys and heart $[7,28,29]$. An increased serum level of urea may be associated with protein catabolism and kidney dysfunction [30]. Treatment with AA could significantly lower the levels of serum ALT and urea as compared with diabetic control rats, while, no significant effect was observed in AST level. Increased creatinine kinase and lactate dehydrogenase content are the major indicators of cellular damage [31]. Usually, these membranes bound enzymes leak out into the plasma during cellular injury due to disintegration of contractile elements and sarcoplasmic reticulum [31]. In present investigation, both lactate dehydrogenase and creatinine kinase levels in the sera were significantly $(\mathrm{p}<0.01)$ elevated in T2D animals (Table 2). However, treatment with AA $(200 \mathrm{mg} / \mathrm{kg})$ could significantly $(\mathrm{p}<$ 0.05 ) revert the levels of lactate dehydrogenase and creatinine kinase as compared with T2D control rats. In this experiment, C-reactive protein activities were significantly up-regulated in diabetic animals. It is reported that the incidence of diabetes is linked with higher levels of various inflammatory parameters like C-reactive proteins [4]. An elevated level of serum Creactive proteins vindicated the inflammation mediated damage of critical tissues. Treatment with AA could significantly $(\mathrm{p}<0.05-0.01)$ reduce the $\mathrm{C}$-reactive protein levels in a dose-dependent manner.

\section{Effect on body and organs' weight}

In the present study, total body weight and the weights of kidney and heart was measured (Table 3). A

Table 3 Effect of AA on body weight and organ weight of T2D rats

\begin{tabular}{llll}
\hline Groups & Total body weight $(\mathbf{g})$ & Kidney weight $\mathbf{( g )}$ & Heart weight (g) \\
\hline Gr I & $216.67 \pm 7.15$ & $0.95 \pm 0.05$ & $0.47 \pm 0.03$ \\
Gr II & $171.67 \pm 5.58^{\#}$ & $1.41 \pm 0.08^{\#}$ & $0.52 \pm 0.03$ \\
Gr III & $188.33 \pm 6.91$ & $1.17 \pm 0.06$ & $0.53 \pm 0.04$ \\
Gr IV & $192.50 \pm 5.44$ & $1.12 \pm 0.09^{*}$ & $0.52 \pm 0.04$ \\
Gr V & $200.83 \pm 8.60^{*}$ & $1.02 \pm 0.06^{* *}$ & $0.51 \pm 0.02$ \\
\hline
\end{tabular}

Data were expressed as mean $\pm \mathrm{SE}(\mathrm{n}=6) .{ }^{\#} p<0.01$ compared with normal control group. ${ }^{*} p<0.05$ compared with diabetic control group. ${ }^{* *} p<0.01$ compared with diabetic control group. Gr I: Normal; Gr I: Normal; Gr II: T2D control, Gr III: T2D + AA (100 mg/kg, p.o.); Gr IV: T2D + AA (200 mg/kg, p.o.); Gr V: T2D + glibenclamide (1 mg/kg, p.o.). 
Table 4 Effect of AA on ROS production, lipid peroxidation (TBARS), protein carbonyation, ubiquinones (coenzyme Q9 and Q10) and GSH level of T2D rats

\begin{tabular}{|c|c|c|c|c|c|}
\hline Parameters & Gr I & Gr II & Gr III & Gr IV & Gr V \\
\hline \multicolumn{6}{|l|}{ Kidney } \\
\hline ROS production (nmol DCF $\mathrm{min}^{-1} \mathrm{mg}^{-1}$ of protein) & $36.84 \pm 3.14$ & $75.47 \pm 4.56^{\#}$ & $53.51 \pm 6.39^{* *}$ & $46.89 \pm 4.39^{* *}$ & $57.85 \pm 3.01^{*}$ \\
\hline Lipid peroxidation (TBARS level in $\mu \mathrm{g} \mathrm{g}^{-1}$ of tissue) & $4.56 \pm 0.32$ & $7.20 \pm 0.45^{\#}$ & $5.56 \pm 0.57^{*}$ & $5.47 \pm 0.33^{*}$ & $5.71 \pm 0.49^{*}$ \\
\hline Protein cabonylation ( $\mathrm{nmol} \mathrm{mg}^{-1}$ of protein) & $8.71 \pm 0.72$ & $17.71 \pm 1.51^{\#}$ & $13.20 \pm 1.32^{*}$ & $11.17 \pm 1.06^{* *}$ & $11.36 \pm 1.27^{* *}$ \\
\hline Total coenzyme Q9 (nmol g ${ }^{-1}$ of wet tissue) & $148.80 \pm 4.31$ & $116.50 \pm 5.46^{\#}$ & $127.33 \pm 4.45$ & $137.71 \pm 5.57^{*}$ & $143.20 \pm 4.61^{* *}$ \\
\hline Total coenzyme Q10 (nmol g ${ }^{-1}$ of wet tissue) & $25.38 \pm 1.66$ & $16.88 \pm 1.78^{\#}$ & $21.75 \pm 1.87$ & $23.60 \pm 1.82^{*}$ & $21.32 \pm 1.73$ \\
\hline GSH (mg g ${ }^{-1}$ tissue) & $25.56 \pm 1.52$ & $15.12 \pm 0.98^{\#}$ & $20.08 \pm 1.43$ & $22.32 \pm 1.87^{* *}$ & $23.60 \pm 1.61^{* *}$ \\
\hline \multicolumn{6}{|l|}{ Heart } \\
\hline ROS production (nmol DCF $\mathrm{min}^{-1} \mathrm{mg}^{-1}$ of protein) & $25.89 \pm 1.46$ & $58.14 \pm 3.84^{\#}$ & $40.77 \pm 3.72^{* *}$ & $37.83 \pm 3.01^{* *}$ & $45.94 \pm 2.82^{* *}$ \\
\hline Lipid peroxidation (TBARS level in $\mu \mathrm{g} \mathrm{g}^{-1}$ of tissue) & $3.55 \pm 0.24$ & $6.30 \pm 0.37^{\#}$ & $5.09 \pm 0.33^{*}$ & $4.61 \pm 0.34^{* *}$ & $4.94 \pm 0.20^{*}$ \\
\hline Protein cabonylation ( $\mathrm{nmol} \mathrm{mg}^{-1}$ of protein) & $2.48 \pm 0.26$ & $5.09 \pm 0.42^{\#}$ & $3.73 \pm 0.27^{*}$ & $3.06 \pm 0.22^{* *}$ & $3.02 \pm 0.31^{* *}$ \\
\hline Total coenzyme Q9 (nmol g ${ }^{-1}$ of wet tissue) & $59.12 \pm 2.88$ & $43.01 \pm 3.15^{\$}$ & $51.03 \pm 3.94$ & $54.44 \pm 3.80$ & $55.46 \pm 4.30^{*}$ \\
\hline Total coenzyme Q10 (nmol g ${ }^{-1}$ of wet tissue) & $26.87 \pm 2.45$ & $15.84 \pm 1.93^{\$}$ & $22.42 \pm 3.18$ & $25.80 \pm 2.77^{*}$ & $25.05 \pm 2.42$ \\
\hline GSH (mg g ${ }^{-1}$ tissue) & $22.13 \pm 1.54$ & $12.28 \pm 1.78^{\#}$ & $17.40 \pm 2.39$ & $19.60 \pm 1.24^{*}$ & $19.31 \pm 1.92^{*}$ \\
\hline
\end{tabular}

Data were expressed as mean $\pm \mathrm{SE}(\mathrm{n}=6) .{ }^{\$} p<0.05$ compared with normal control group. ${ }^{*} p<0.01$ compared with normal control group. ${ }^{*} p<0.05$ compared with diabetic control group. ${ }^{* *} p<0.01$ compared with diabetic control group. Gr I: Normal; Gr I: Normal; Gr II: T2D control, Gr III: T2D + AA (100 mg/kg, p.o.); Gr IV: T2D + AA (200 mg/kg, p.o.); Gr V: T2D + glibenclamide (1 mg/kg, p.o.).

significant $(\mathrm{p}<0.01)$ decrease of body weight was noticed in diabetic control animals. Extract treatment in either of doses, though statistically insignificant, but definitely improved body weight of T2D rats. In T2DM, loss of insulin responsiveness prevented utilization of glucose for energy to the cells. Under this situation, body starts burning fat and muscle for energy, which would be accountable for loss of body weight in diabetic control rats. In this study, a significant increase $(\mathrm{p}<0.01)$ in kidney weight was observed in diabetic control group as compared with normal control rats. The enhancement of kidney weight would be accountable to glomerular hypercellularity, increase in mesangium and subsequent closer of glomerulus. Treatment with AA $(200 \mathrm{mg} / \mathrm{kg})$ could significantly $(\mathrm{p}<0.05)$ reverse this effect near to the normal status. However, no significant changes were observed in weight of heart in any of experimental animal.

Table 5 Effect of AA on antioxidant enzymes viz. CAT, SOD, GST, GPx, G6PD and GR of T2D rats

\begin{tabular}{|c|c|c|c|c|c|}
\hline Parameters & Gr I & Gr II & Gr III & Gr IV & Gr V \\
\hline \multicolumn{6}{|l|}{ Kidney } \\
\hline CAT ( $\mathrm{U} \mathrm{mg} \mathrm{m}^{-1}$ of protein) & $226.34 \pm 16.33$ & $153.74 \pm 9.11^{\#}$ & $207.28 \pm 12.03^{*}$ & $212.65 \pm 13.77^{*}$ & $216.33 \pm 17.88^{*}$ \\
\hline SOD ( $U \mathrm{mg}^{-1}$ of protein) & $140.32 \pm 7.05$ & $98.51 \pm 6.16^{\#}$ & $123.82 \pm 6.07^{*}$ & $129.15 \pm 6.92^{* *}$ & $128.56 \pm 6.94^{*}$ \\
\hline GST ( $\mu \mathrm{mol} \mathrm{h} \mathrm{h}^{-1} \mathrm{mg}^{-1}$ of protein) & $0.71 \pm 0.07$ & $0.46 \pm 0.04^{\$}$ & $0.59 \pm 0.05$ & $0.68 \pm 0.06^{*}$ & $0.67 \pm 0.04^{*}$ \\
\hline GPx (nmol $\mathrm{min}^{-1} \mathrm{mg}^{-1}$ of protein) & $68.20 \pm 5.91$ & $40.43 \pm 5.57^{\$}$ & $54.20 \pm 6.12$ & $59.93 \pm 8.63$ & $61.82 \pm 6.64$ \\
\hline $\mathrm{GR}$ (nmol $\mathrm{min}^{-1} \mathrm{mg}^{-1}$ of protein) & $69.81 \pm 4.90$ & $41.82 \pm 3.31^{\#}$ & $59.48 \pm 5.63$ & $61.63 \pm 5.74^{*}$ & $63.85 \pm 6.30^{*}$ \\
\hline G6PD (nmol $\mathrm{min}^{-1} \mathrm{mg}^{-1}$ of protein) & $133.64 \pm 7.07$ & $97.44 \pm 5.19^{\#}$ & $117.65 \pm 7.69$ & $125.38 \pm 8.57^{*}$ & $126.41 \pm 6.45^{*}$ \\
\hline \multicolumn{6}{|l|}{ Heart } \\
\hline CAT (U mg ${ }^{-1}$ of protein) & $287.50 \pm 11.61$ & $192.26 \pm 10.52^{\#}$ & $230.63 \pm 16.50$ & $255.41 \pm 15.18^{*}$ & $254.98 \pm 20.62^{*}$ \\
\hline $\mathrm{SOD}\left(\mathrm{U} \mathrm{mg}^{-1}\right.$ of protein) & $133.66 \pm 7.54$ & $95.14 \pm 4.66^{\#}$ & $115.45 \pm 7.67$ & $121.96 \pm 7.18^{*}$ & $123.60 \pm 7.82^{*}$ \\
\hline GST ( $\mu \mathrm{mol} \mathrm{h} \mathrm{h}^{-1} \mathrm{mg}^{-1}$ of protein) & $1.63 \pm 0.13$ & $1.07 \pm 0.12^{\#}$ & $1.47 \pm 0.10$ & $1.53 \pm 0.13^{*}$ & $1.55 \pm 0.11^{*}$ \\
\hline GPx (nmol $\mathrm{min}^{-1} \mathrm{mg}^{-1}$ of protein) & $81.49 \pm 8.08$ & $96.74 \pm 7.01^{\#}$ & $133.45 \pm 10.13^{*}$ & $138.62 \pm 10.69^{*}$ & $139.69 \pm 8.35^{* *}$ \\
\hline $\mathrm{GR}$ (nmol $\mathrm{min}^{-1} \mathrm{mg}^{-1}$ of protein) & $26.87 \pm 2.45$ & $50.20 \pm 4.29^{\#}$ & $67.20 \pm 4.70$ & $73.28 \pm 6.67^{*}$ & $75.08 \pm 4.69^{*}$ \\
\hline G6PD (nmol $\mathrm{min}^{-1} \mathrm{mg}^{-1}$ of protein) & $101.70 \pm 7.04$ & $71.23 \pm 4.22^{\#}$ & $88.48 \pm 6.29$ & $94.55 \pm 4.03^{*}$ & $92.90 \pm 4.43^{*}$ \\
\hline
\end{tabular}

Data were expressed as mean $\pm \mathrm{SE}(\mathrm{n}=6) .{ }^{5} p<0.05$ compared with normal control group. ${ }^{*} p<0.01$ compared with normal control group. ${ }^{*} p<0.05$ compared with diabetic control group. ** $<0.01$ compared with diabetic control group. Gr I: Normal; Gr II: T2D control, Gr III: T2D + AA (100 mg/kg, p.o.); Gr IV: T2D + AA (200 mg/kg, p.o.); Gr V: T2D + glibenclamide (1 mg/kg, p.o.). 


\section{Effect on renal and cardiac antioxidant markers}

Imbalance in cellular redox status due to oxidative stress participate a crucial role in diabetic pathophysiology [5]. The experimental observation confirmed that renal and cardiac dysfunctions resulting from diabetes were accompanied with an alteration in the redox status within the tissues (Tables 4 and 5). The rate of ROS production in diabetic control group was found to be significantly $(\mathrm{p}<0.01)$ higher than that of the normal animals. The inexorable generation of ROS during T2DM could be correlated with the significantly $(\mathrm{p}<0.01)$ elevated levels of lipid peroxidation (TBARS) and protein carbonylation in T2D rats. Lipid peroxidation and protein carbonyl content are the indication of cell membrane damage and oxidative modification of proteins. Treatment with AA $\left(100\right.$ and $\left.200 \mathrm{mg} \mathrm{kg}^{-1}\right)$, however, could significantly $(\mathrm{p}<$ 0.01 ) inhibit the rate of ROS production in the selected tissues as compared to diabetic rats. Thereby, AA (100 and $\left.200 \mathrm{mg} \mathrm{kg}^{-1}\right)$ could simultaneously alleviate $(\mathrm{p}<0.05-$ 0.01 ) that lipid peroxidation and protein carbonylation in renal and myocardial tissues. Ubiquinones (co-enzymes Q) function as important cellular electron carriers distributed within cell organelles chiefly in mitochondria [32].
Co-enzymes $\mathrm{Q}_{9}$ and $\mathrm{Q}_{10}$ act as antioxidants through scavenging ROS and thereby inhibit lipid peroxidation. A significant reduction of co-enzymes Q (Q9 and Q10) levels in renal $(\mathrm{p}<0.01)$ and cardiac $(\mathrm{p}<0.05)$ tissues was observed in T2D control rats as compared with normal control animals. AA (200 $\left.\mathrm{mg} \mathrm{kg}^{-1}\right)$ treatment could significantly $(\mathrm{p}<0.05)$ improve Q9 level in kidneys and Q10 levels in kidneys and hearts in T2D animals. Thiol-based antioxidant system (GSH) contributes in cellular defense against free radicals mediated oxidative damage. It protects cells from ROS and consequently converted into its oxidized form, GSSG [29]. According to the present data, the level of GSH decreased significantly $(\mathrm{p}<0.01)$ due to T2DM in rats as compared with normal animals. Oral administration of AA $(200 \mathrm{mg} / \mathrm{kg})$ could ameliorate this alteration in renal $(\mathrm{p}<0.01)$ and cardiac $(\mathrm{p}<0.05)$ tissues as compared with diabetic control animals, which would be perhaps due to strong anti-radical activity of AA. Antioxidant enzymes viz. CAT, SOD, GPx, GST, G6PD and GR are first line of cellular defense against oxidative stress [33]. In present study, T2DM caused significant depletion in antioxidant enzymes in cardiac and renal tissues (Table 5). Excessive generation of ROS is accountable for

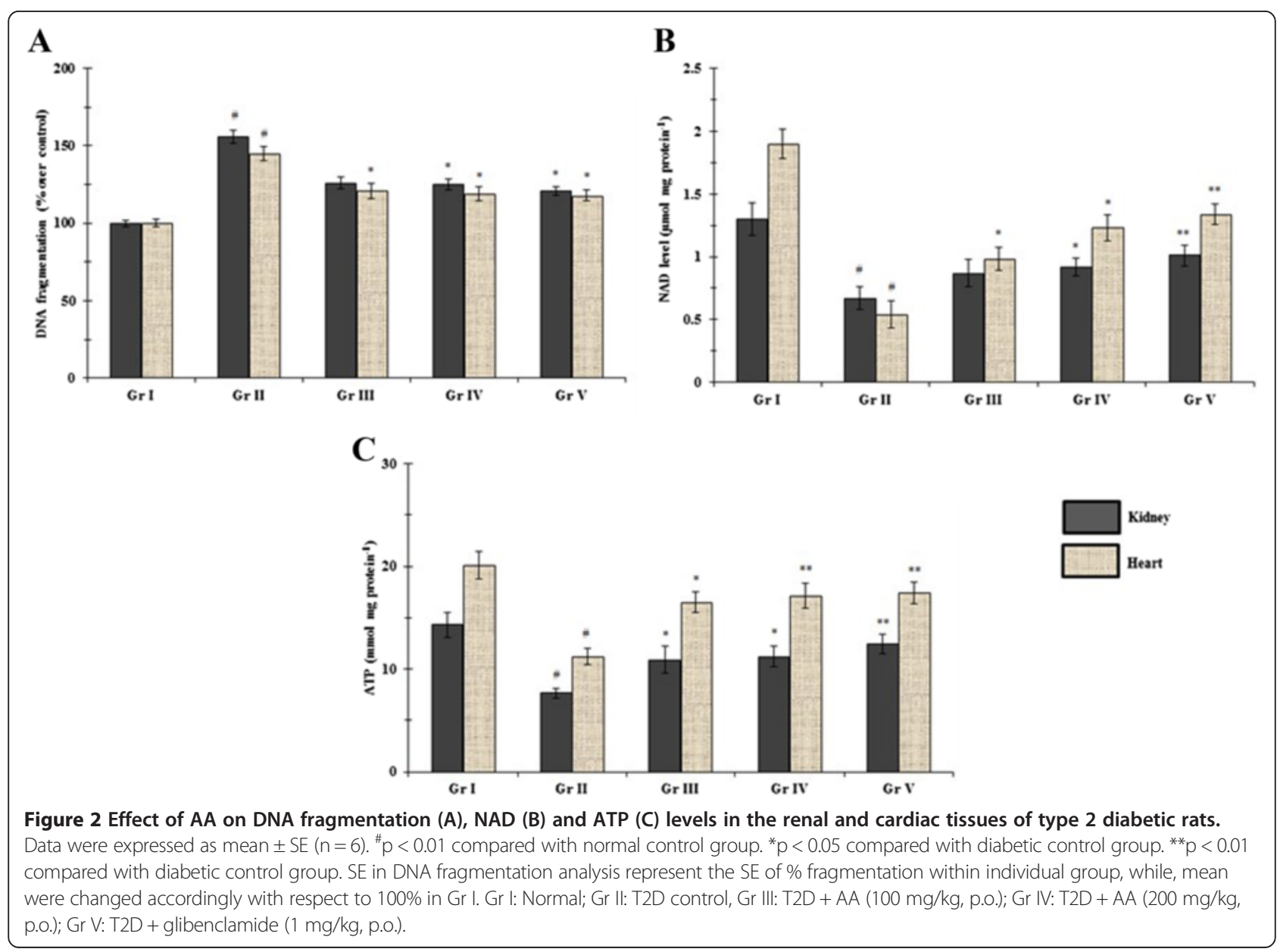


decreasing the activities of antioxidant enzymes in T2DM. While, AA treatment could significantly restore the activities of antioxidant enzymes. The augmented oxidative stress in T2DM was successfully turned-back by AA supplementation indicating its prophylactic potential against oxidative stress and associated dysfunctions in kidneys and heart of T2D rats. The extract may perform its function by electron-transfer, radical recombination, radical addition and/or by quenching free radicals.

\section{Effect on DNA fragmentation, NAD and ATP levels}

Intercellular redox imbalance plays a key role in DNA damage. The most reactive - $\mathrm{OH}$ radical reacts with DNA bases and subtract a hydrogen atom from methyl group of thymine base. As a result, DNA strands are ruptured, or DNA bases are modified abnormally or DNAs are crosslinked. The DNA fragmentation and PARP activation play a pivotal role in cell-death process in diabetic pathophysiology [34]. The DNA fragmentation percentage in renal and myocardial tissues of experimental rats was depicted in Figure 2A. T2DM increased DNA fragmentation in renal and myocardial tissues significantly $(\mathrm{p}<0.01)$ amounting $\sim 145$ and $156 \%$, respectively. Oral administration of AA $(200 \mathrm{mg} / \mathrm{kg})$ inhibited DNA fragmentation in T2D rats, significantly $(\mathrm{p}<0.05)$. In this study, intracellular ATP and NAD levels in the selected tissues were investigated (Figure $2 \mathrm{~B}$ and $\mathrm{C}$, respectively). It was observed that, hyperglycemia caused significant $(\mathrm{p}<$ $0.01)$ reduction in intracellular NAD and ATP levels in renal and cardiac tissues of diabetic control rats. Activation of inflammatory cytokines induces necrosis via PARP activation during T2DM, which would be accountable for the reduction of intracellular ATP levels. Reduction of ATP level suggested that necrosis simultaneously participate in diabetic pathophysiology. AA treatment, however, could significantly reinstate in cellular ATP $(\mathrm{p}<0.05)$ and NAD $(\mathrm{p}<0.05-0.01)$ levels in both the tissues. Therefore, it would be suggested that AA supplementation could protect renal and myocardial tissues from adverse effects of T2DM by preventing DNA damage and PARP activation.

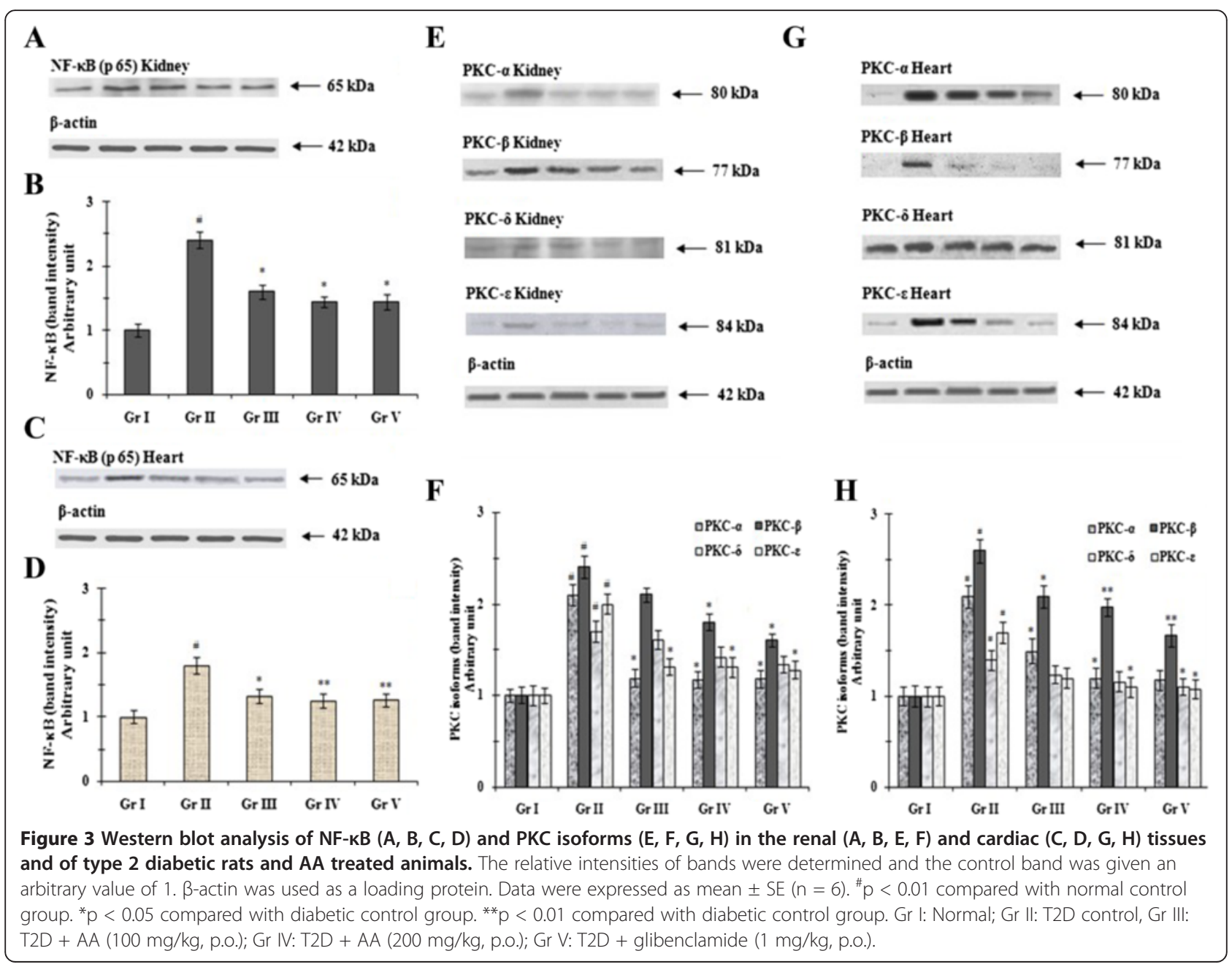




\section{Effect on signal proteins}

NF- $\mathrm{kB}$, a ubiquitous transcription factor, gets activated in response to oxidative stress. NF- $\mathrm{B}$ plays integral role in regulation of various inflammatory and immune responses [35]. Therefore the expressions of NF-kB have been investigated in the kidneys (Figure 3A,B) and hearts (Figure 3C,D) tissues of experimental animals under different groups. Interestingly, the expressions of NF- $k B$ were significantly $(\mathrm{p}<0.01)$ increased in renal and myocardial tissues of T2D rats. However, treatment with AA (100 and $200 \mathrm{mg} / \mathrm{kg}$ ) could significantly ( $<$ $0.05-0.01)$ reinstate the expressions of NF- $\mathrm{kB}$ in the selected tissues near to normalcy. Activation of PKCs within cells during T2DM results in various pathophysiological changes [4]. PKCs are activated via polyol pathway during hyperglycemia [4]. Activated PKC isoforms attribute many abnormal vascular and cellular processes and deregulations viz. endothelial dysfunction, vascular permeability, angiogenesis, apoptosis, changes in vessel dilation, basement membrane thickening, and extracellular matrix expansion, alterations of enzymatic activities and alterations in several transcription proteins [36,37]. Also, PKCs could activate the expression of $\mathrm{NF}-\mathrm{\kappa B}$ under oxidative stress [38]. Earlier reports revealed that PKC isoforms (PKC- $\alpha, \beta, \delta$, and $\varepsilon$ ) are activated in hyperglycemiamediated nephropathy and cardiomyopathy [37,39]. Different isoforms of PKCs were evaluated through immunoblotting (Figure 3E-H). Immunoblot assays indicated that, T2D rats exhibited significantly $(\mathrm{p}<0.01)$ up-regulated expressions of PKC- $\alpha$, PKC- $\beta$, PKC- $\delta$ and $\mathrm{PKC}-\varepsilon$ in renal (Figure 3E,F) and myocardial (Figure 3G, $\mathrm{H})$ tissues. However, the treatment with AA could significantly $(\mathrm{p}<0.05-0.01)$ reduce the expression of $\mathrm{PKC}$ isoforms in diabetic rats.

Finally, T2D-mediated intrinsic apoptotic cell death pathway in renal and cardiac tissues was studied (Figure 4). Oxidative stress seems to play a crtitical role in mitochondrial dysfunction which is an important early event in the

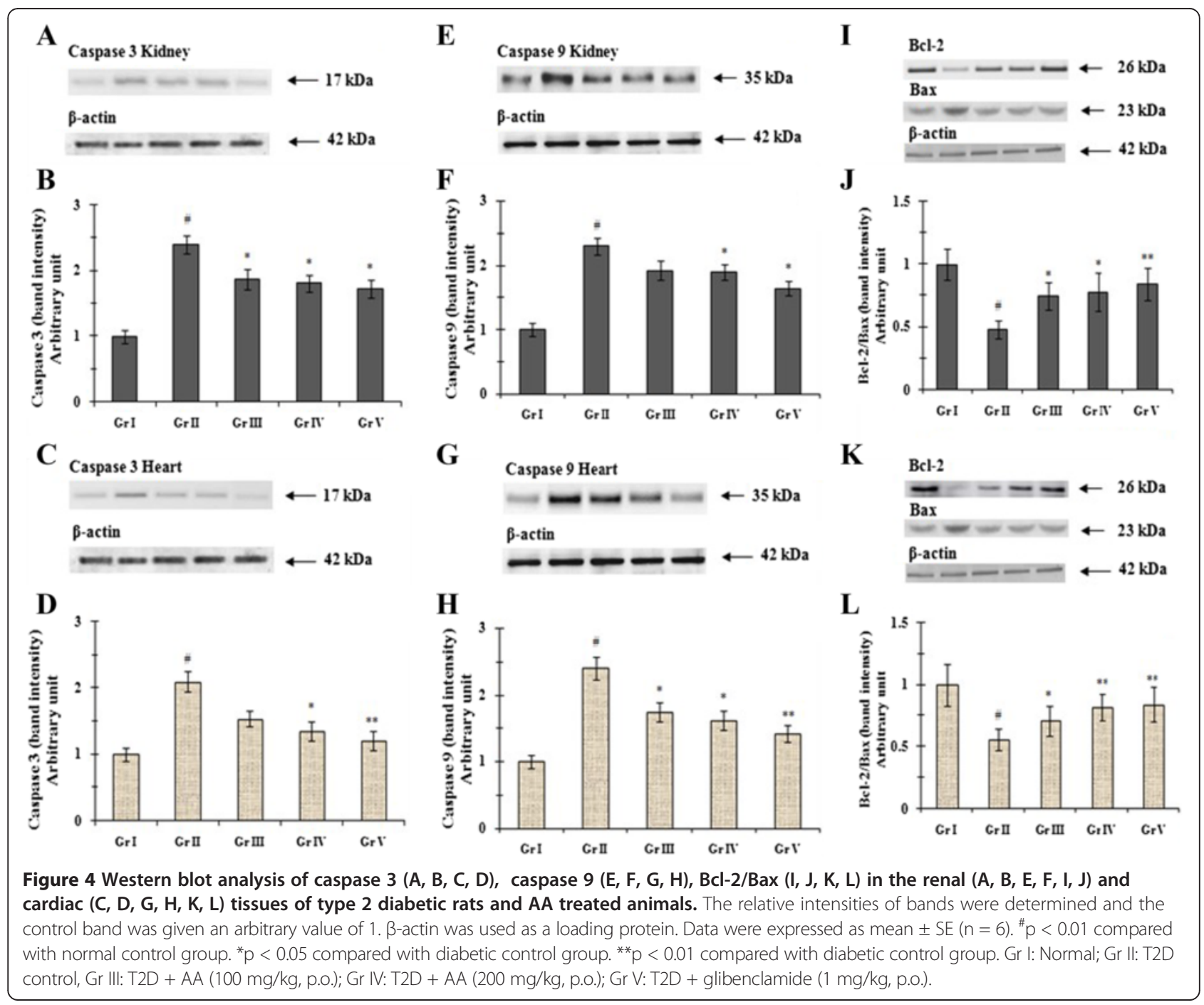




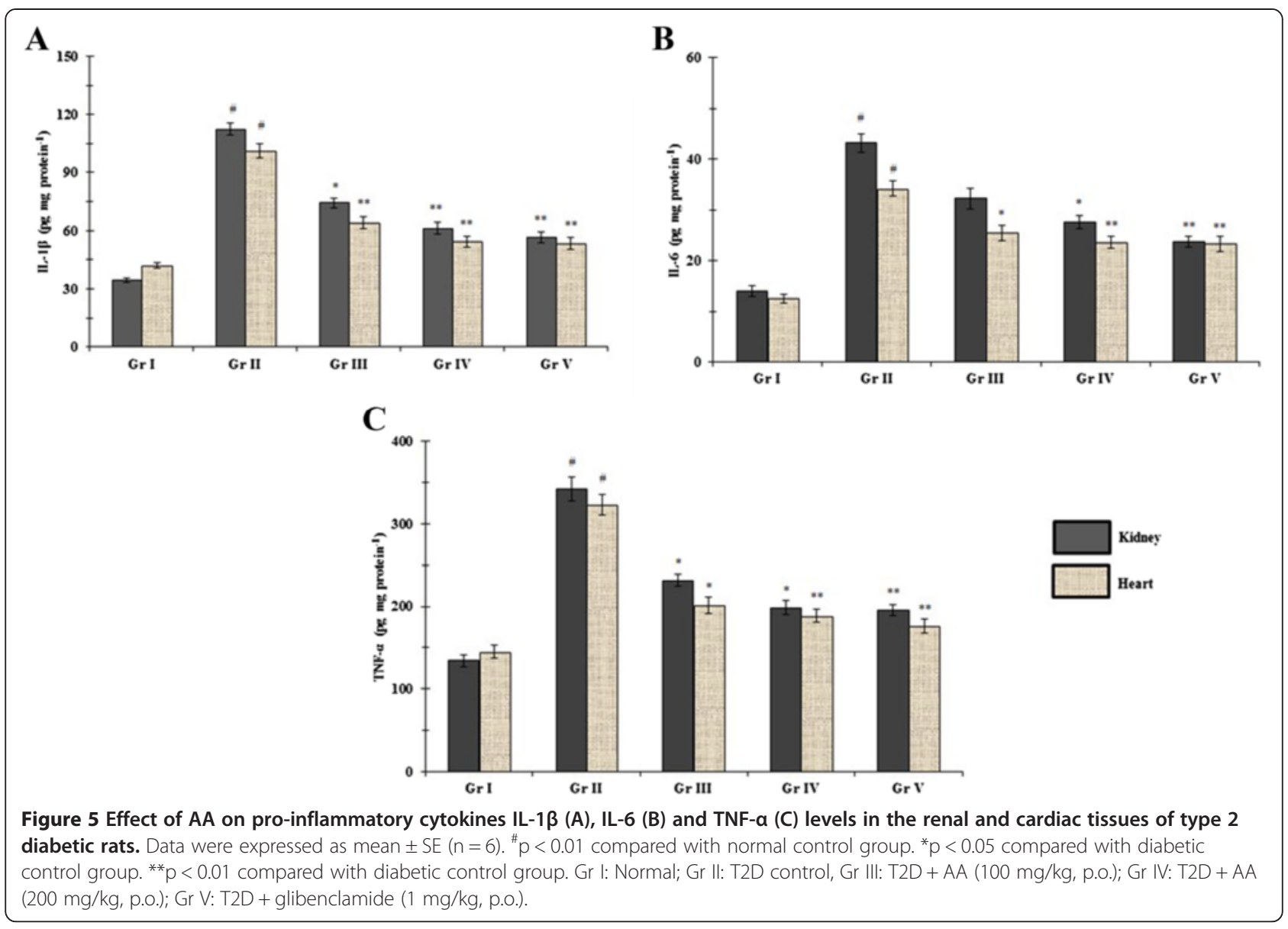

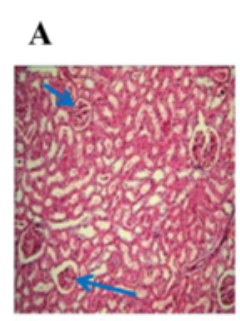

Gr I

B

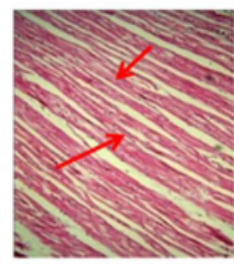

Gr I

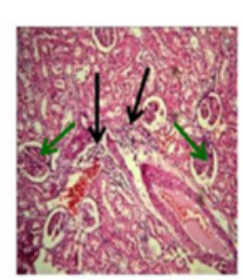

Gr II

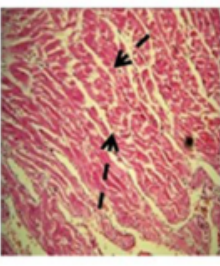

Gr II

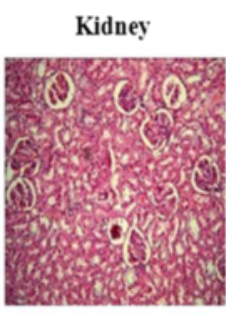

Gr III

Heart

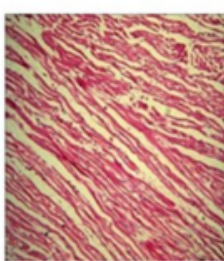

Gr III

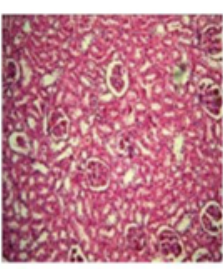

Gr IV

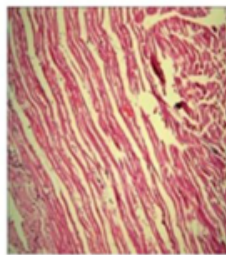

Gr IV

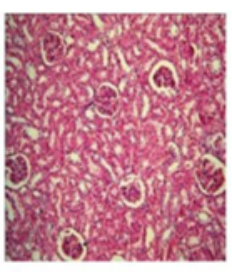

Gr V

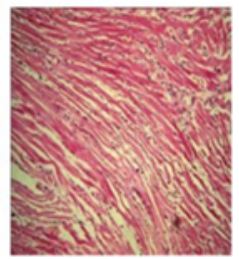

Gr V

Figure 6 Histological sections (X 20) of kidneys (Panel A) and heart (Panel B) of normal rats (Gr I), type 2 diabetic rats (Gr II), type 2 diabetic rat treated with AA $(100 \mathrm{mg} / \mathrm{kg})(\mathrm{Gr}$ III), type 2 diabetic rat treated with AA $(200 \mathrm{mg} / \mathrm{kg})(\mathrm{Gr} I V)$, type 2 diabetic rat treated with glibenclamide (1 $\mathrm{mg} / \mathrm{kg}$ ) (Gr V). Blue arrows represent normal glomerular structure. The green arrows showed glomerular hypercellularity. The black arrows indicated tubular necrosis. The red arrows indicated normal radiating pattern of cardiac muscle. The black dotted arrows showed extensive degeneration in cardiac muscle. Gr I: Normal; Gr II: T2D control, Gr III: T2D + AA (100 mg/kg, p.o.); Gr IV: T2D + AA (200 mg/kg, p.o.); Gr V: T2D + glibenclamide (1 mg/kg, p.o.). 
intrinsic pathway of apoptosis. The prime executers of the apoptotic pathways are some pro- and anti-apoptotic proteins and cysteinyl aspartic acid-specific proteases (caspases) $[7,40]$. Proteins of the Bcl-2 (anti-apoptotic) family act on the mitochondria to regulate the release of cytochrome $\mathrm{c}$ and initiate the caspases dependent apoptotic pathway [7]. Bax is a pro-apoptotic protein and can modulate the pro-apoptotic processes by inhibiting the expression of Bcl-2 members. Immunoblot analyses of caspase 3 (Figure 4A-D) and caspase 9 (Figure 4E-H) exhibited significant $(\mathrm{p}<0.01)$ up-regulation of caspases in renal and cardiac tissues of T2D rats, which indicated apoptotic cell damage in selected tissues with the progression of DM. Treatment with AA, however, could significantly $(\mathrm{p}<0.05)$ arrest the over-expression of caspases in renal and myocardial tissues of T2D rats. In this study, T2DM inhibited $\mathrm{Bcl}-2$ significantly and activated the Bax expressions. Therefore, the Bcl-2 to Bax ratio was significantly ( $\mathrm{p}<0.01)$ reduced in the kidney (Figure 4I,J) and hearts (Figure 4K,L) of diabetic control rats. Supplementation of AA restored the $\mathrm{Bcl}-2 / \mathrm{Bax}$ ratio thereby preventing the Bax translocation to mitochondrial membranes. The experimental outcome could suggest that the AA treatment could attenuate mitochondria dependent cell death pathway.

\section{Effect on inflammatory mediators}

There are mounting evidences that, pro-inflammatory cytokine viz. IL-6, IL-1 $\beta$ and TNF- $\alpha$ play a key role in the development of diabetic cardiomyopathy and nephropathy [4]. An increase in NF- $\mathrm{KB}$ expression leads to a consequent increase in the concentrations of aforementioned inflammatory cytokines in diabetic rats which are in-line with previous studies $[4,35]$. Pro-inflammatory cytokines are chief mediators of inflammatory reaction and stimulate the generation of acute phase proteins. These cytokines function inter-dependently. For example, IL-6 works in connection with IL- $1 \beta$ for synthesis of C-reactive proteins [41]. The TNF- $\alpha$ stimulates hyperlipidemia and hepatic lipogenesis simultaneously reducing the sensitivity to insulin in muscle tissues [42] and finally the necrosis of target organs. In this study, a significant $(\mathrm{p}<0.01)$ increase in the concentrations of pro-inflammatory cytokines was observed in T2DM rats (Figure 5A-C). However, supplementation of AA could significantly reduce the levels of IL-6, IL-1 $\beta$ and TNF- $\alpha$ in the renal and cardiac tissues of diabetic rats in a dose-dependent manner. AA would perhaps act through inhibition of NF-kB expression.

\section{Effect on histology of organs}

Histological study of the kidney tissues indicated that normal cyto-architecture of glomerulus was maintained in control rats (Figure 6, Panel A, Gr I), while, cellular necrosis and glomerular hypercellularity was observed in T2D rats (Figure 6, Panel A, Gr II). Rats receiving AA (100 and $200 \mathrm{mg} / \mathrm{kg}$ ) restored nearly normal glomerular structures and renal tubules (Figure 6, Panel A, Gr III

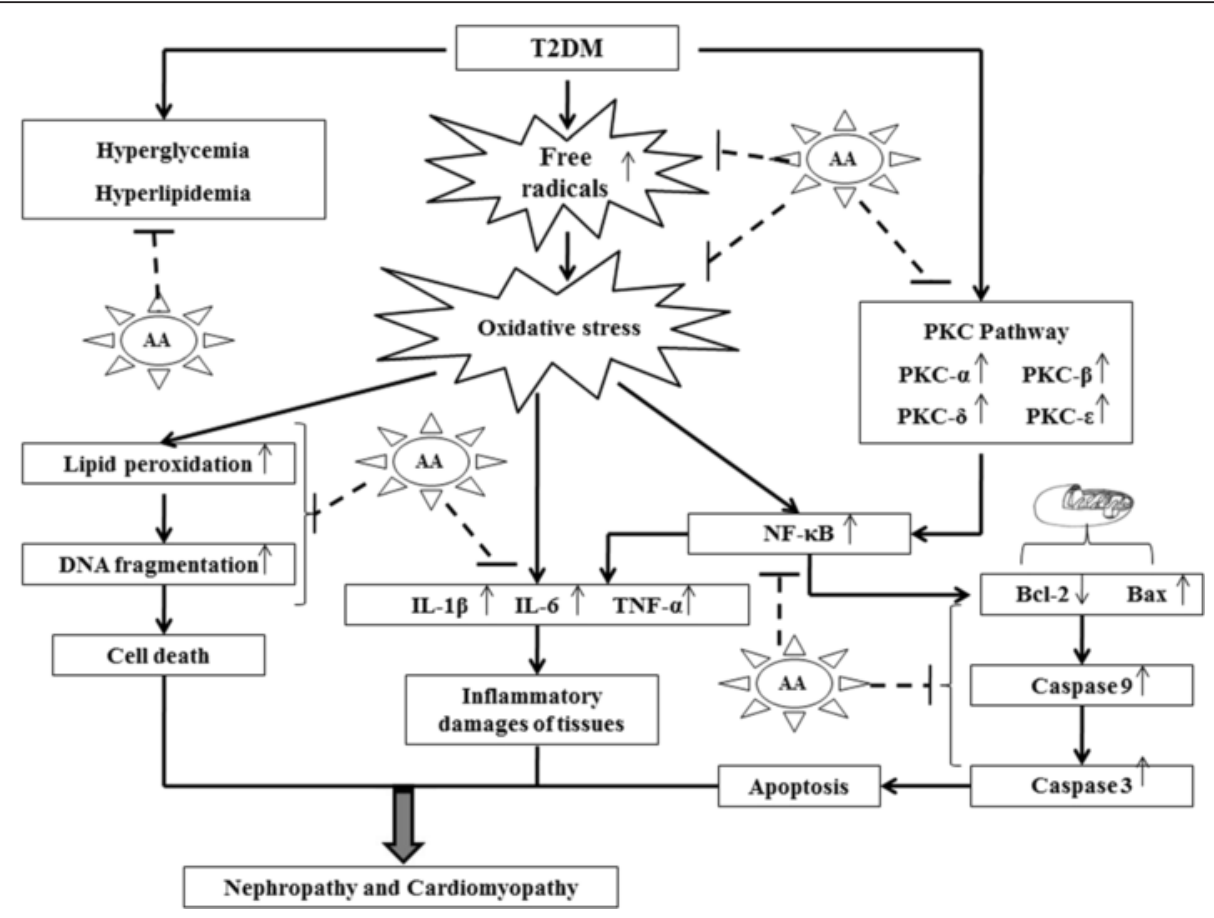

Figure 7 Schematic diagram of the T2DM mediated renal and cardiac dysfunction and prophylactic role of AA. Dotted lines represent the therapeutic sites of AA. 
and IV, respectively). T2DM lead to vast degeneration in cardiac muscles and interstitial fibrosis (Figure 6, Panel B, Gr II) as compared with normal rats (Figure 6, Panel B, Gr I). Supplementation with AA can prevent the disorganization of cell plates and can restore the cardiac cyto-architecture (Figure 6, Panel B, Gr III and IV, respectively) nearly similar to that of normal rats. Glibenclamide, a standard drug (oral hypoglycemic), was used as a reference standard and the effect of AA was compared with glibenclamide $(1 \mathrm{mg} / \mathrm{kg})$. The effect of AA at the dose of $200 \mathrm{mg} / \mathrm{kg}$ was remained more or less equivalent to that of comparable to that of glibenclamide $(1 \mathrm{mg} / \mathrm{kg})$ treated type 2 diabetic animals.

Phytochemical analysis revealed presence of taraxerol which is reported to act as stimulator of glycogen synthesis in 3 T3-L1 adipocytes and as glucose-transport activator [43]. Taraxerol is also reported to reverse insulin resistance [44] and possesses anti-inflammatory properties [45]. Beside taraxerol, AA also contains significant quantity of flavonoids and phenolic constituents which are known phyto-antioxidants [7]. Therefore, a multimodal effect could be achieved due to presence of aforementioned bio-active phytochemicals.

Earlier literatures claimed the prophylactic role of $A$. augusta in diabetes [46]. Islam et al. [10] reported that the aqueous extract of $A$. augusta leaves would be beneficial in managing T2DM. Halim [46] reported the prophylactic role of of aqueous extracts $A$. augusta roots and $A$. indica leaves in combination (1:1). However, both these studies employed alloxan-rats for antidiabetic assay. Despite Islam et al. [10] claimed the effectiveness of $A$. augusta leaves against T2DM but the experimental protocol strongly recommends the development of T1DM in rats which were subjected for their assay. Along with, neither of these published literatures could substantiate any mechanism of A. augusta leaves in diabetic pathophysiology nor to establish a correlation between phytochemicals and the observed activity. On other hand, in our study an acceptable model [15] of T2DM has been used to screen antidiabetic effect of A. augusta leaves. Supportive data have been presented to show the effect of streptozotocin (singly) and streptozotocin-nicotinamide (combination) on experimental rats to support the experimental model. Significant attempts have made to show the mechanism of action of the test material in diabetic pathophysiology. Finally, the activity has been correlated with phytochemicals present within the A. augusta leaves.

In conclusion, this study first demonstrated that AA effectively inhibited hyperglycemia and hyperlipidemia in T2DM, which may be due to presence of sufficient amounts of taraxerol. Supplementation of AA decreased oxidative stress and related inflammatory responses of the heart and kidneys to provide reno-protection and cardio-protection in type 2 diabetic rats. The antioxidant effect could be correlated to presence of phenolic compounds and flavonoids, while anti-inflammatory effect could be due to taraxerol. Moreover, AA can reduce the PKCs activation, NF- $\mathrm{KB}$ and mitochondriadependent apoptotic signaling cascades. The overall beneficiary, multimodal effect of AA has been depicted in Figure 7. With these benefits and absence of any adverse effects, AA may be used to treat T2DM and its associated nephropathy and cardio-myopathy. The results provide a justification for future clinical trials of $A$. augusta extract (chemically defined) for the development of oral hypoglycemic agent employing natural resources.

\section{Additional file}

Additional file 1: Consists of supportive data on phytochemical investigation of defatted methanol extract of $A$. augusta extract. Figure S1. described the physical and spectroscopic data of isolated compounds from A. augusta. Figure S2. depicted the HPLC chromatograms of standard flavonoid markers and flavonoids present within the test extract. Figure S3. showed HPLC chromatograms of standard phenolic markers and phenolic compounds present within the test extract.

\section{Competing interests}

The authors declare that they have no competing interests.

\section{Authors' contributions}

SD designed the experiments, supervised and participated entire work. RK and TKD performed animal studies, biochemical analysis and phytochemical analysis. RK, RS and MG performed Western blot analysis. MZUH and VDF put important views to during designing of experiment and writing the manuscript. All authors read and approved the final manuscript.

\section{Acknowledgements}

The financial support of the Indian Council for Medical Research, New Delhi, India through the fellowship to Ms. Ritu Khanra is gratefully acknowledged. Authors would also acknowledge to Jadavpur University, Kolkata, India for providing necessary facilities for this experiment. Finally, the authors would like to say thanks to the reviewers for their time and valuable comments to improve the quality of this manuscript.

\section{Author details}

${ }^{1}$ Advanced Pharmacognosy Research Laboratory, Department of Pharmaceutical Technology, Jadavpur University, Kolkata 700032, India. ${ }^{2}$ Biophysics Division, Saha Institute of Nuclear Physics, Kolkata 700064, India. ${ }^{3}$ Department of Pharmacy, University of Salerno, Fisciano, Salerno 84084, Italy. ${ }^{4}$ Office of Research, Innovation and Commercialization, Lahore College for Women University, Lahore 54600, Pakistan.

Received: 8 October 2014 Accepted: 16 December 2014

Published online: 16 January 2015

\section{References}

1. Bukhari SA, Shamshari WA, Rahman M, Zia-UI-Haq M, Jaafar HZE. Computer aided screening of secreted frizzled-related protein 4 (SFRP4): a potential control for diabetes mellitus. Molecules. 2014;19:10129-36.

2. Fernández-Millán E, Ramos S, Alvarez C, Bravo L, Goya L. Microbial phenolic metabolites improve glucose-stimulated insulin secretion and protect pancreatic beta cells against tert-butyl hydroperoxide-induced toxicity via ERKs and PKC pathways. Food Chem Toxicol. 2014;66:245-53.

3. Deutschländer MS, Lall N, Van de Venter M, Dewanjee S. The hypoglycemic activity of Euclea undulata Thunb. var. myrtina (Ebenaceae) root bark evaluated in a streptozotocin-nicotinamide induced type 2 diabetes rat model. S Afr J Bot. 2012;80:9-12. 
4. Bhattacharya S, Manna P, Gachhui R, Sil PC. D-Saccharic acid 1,4-lactone protects diabetic rat kidney by ameliorating hyperglycemia-mediated oxidative stress and renal inflammatory cytokines via NF-KB and PKC signaling. Toxicol Appl Pharmacol. 2013;267:16-29.

5. Dewanjee S, Das AK, Sahu R, Gangopadhyay M. Antidiabetic activity of Diospyros peregrina fruit: effect on hyperglycemia, hyperlipidemia and augmented oxidative stress in experimental type 2 diabetes. Food Chem Toxicol. 2009:47:2679-85.

6. Kikkawa R. Chronic complications in diabetes mellitus. Br J Nutr. 2000;84:S183-5.

7. Dewanjee S, Gangopadhyay M, Sahu R, Karmakar S. Cadmium induced pathophysiology: prophylactic role of edible jute (Corchorus olitorius) leaves with special emphasis on oxidative stress and mitochondrial involvement. Food Chem Toxicol. 2013;60:188-98.

8. Ayalasomayajula SP, Kompella UB. Subconjunctivally administered celecoxibPLGA microparticles sustain retinal drug levels and alleviate diabetesinduced oxidative stress in a rat model. Eur J Pharmacol. 2005;511:191-8.

9. Islam T, Rahman A, Islam AU. Effects of aqueous extract of fresh leaves of Abroma augusta $\mathrm{L}$. on oral absorption of glucose and metformin hydrochloride in experimental rats. ISRN Pharmaceutics. 2013, Article ID 472586: doi:10.5402/2012/472586

10. Das S, Datta R, Nandy S. Antipyretic and analgesic effect of methanolic extract of different parts of Abroma augusta Linn. Asian J Pharm Clin Res. 2012;6:129-33.

11. Islam T, Rahman A, Islam AU. In vitro effect of aqueous extract of fresh leaves of Abroma augusta $L$ on the diffusion of glucose. Bangladesh Pharm J. 2013;16:21-6.

12. Gupta B, Nayak S, Solanki S. Abroma Augusta Linn: a review. Der Pharm Sin. 2011;2:253-61

13. Public Health Service (PHS). Public health service policy on humane care and use of laboratory animals. US Department of Health and Human Services, Washington, DC. Available from Office for Protection from Research Risks, Building 31, Room 4B09, NIII, Bethesda, MD 20892,1986.

14. Kar A, Choudhary BK, Bandyopadhyay NG. Preliminary studies on the inorganic constituents of some indigenous hypoglycaemic herbs on oral glucose tolerance test. J Ethnopharmacol. 1999;64:179-84

15. Masiello P, Broca C, Gross R, Roye M, Manteghetti M. Experimental NIDDM: development of a new model in adult rats administered streptozotocin and nicotinamide. Diabetes. 1998:47:224-9.

16. Nayak SS, Pattabiraman TN. A new colorimetric method for the estimation of glycosylated hemoglobin. Clin Chim Acta. 1981;109:267-74

17. LeBel CP, Bondy SC. Sensitive and rapid quantitation of oxygen reactive species formation in rat synaptosomes. Neurochem Int. 1990;17:435-40.

18. Kim J, McCarte RJM, Yu BP. Influence of age, exercise and dietary restriction on oxidative stress in rats. Aging Clin Exp Res. 1996;8:123-9.

19. Ohkawa H, Ohishi N, Yagi K. Assay for lipid peroxides in animal tissues by thiobarbituric acid reaction. Arch Biochem Biophys. 1979:95:351-8.

20. Uchida K, Stadtman ER. Covalent attachment of 4-hydroxynonenal to glyceraldehydes-3-phosphate dehydrogenase. J Biol Chem. 1993;268:6388-93.

21. Zhang Y, Aberg F, Appelkvist EL, Dallner G, Ernster L. Uptake of dietary coenzyme Q supplement is limited in rats. J Nutr. 1995;125:446-53.

22. Hissin PJ, Hilf R. A fluorometric method for the determination of oxidized and reduced glutathione in tissues. Anal Biochem. 1973;74:214-6.

23. Ghosh J, Das J, Manna P, Sil PC. Protective effect of the fruits of Terminalia arjuna against cadmium-induced oxidant stress and hepatic cell injury via MAPK activation and mitochondria dependent pathway. Food Chem. 2010;123:1062-75.

24. Matsumura H, Miyachi S. Cycling assay for nicotinamide adenine dinucleotides. Methods Enzymol. 1980;69:465-70.

25. Das AK, Dewanjee S, Sahu R, Dua TK, Gangopadhyay M, Sinha MK. Protective effect of Corchorus olitorius leaves against arsenic-induced oxidative stress in rat brain. Environ Toxicol Pharmacol. 2010;29:64-9.

26. Dewanjee S, Maiti A, Sahu R, Dua TK, Mandal V. Effective control of type 2 diabetes through antioxidant defense by edible fruits of Diospyros peregrina. Evi Based Compliment Alter Med. 2011, Article ID 675397: doi:10.1093/ecam/nep080.

27. Pari L, Monisha P, Jalaludeen AM. Beneficial role of diosgenin on oxidative stress in aorta of streptozotocin induced diabetic rats. Eur J Pharmacol. 2012;691:143-50.

28. Kireev R, Bitoun S, Cuesta S, Tejerina A, Barrola C. Melatonin treatment protect sliver of Zucker rats after ischemia/reperfusion by diminishing oxidative stress and apoptosis. Eur J Pharmacol. 2013;701:185-93.
29. Dutta M, Ghosh D, Ghosh AK, Bose G, Chattopadhyay A. High fat diet aggravates arsenic induced oxidative stress in rat heart and liver. Food Chem Toxicol. 2014;66:262-77.

30. Dewanjee S, Sahu R, Karmakar S, Gangopadhyay M. Toxic effects of lead exposure in Wistar rats: involvement of oxidative stress and the beneficial role of edible jute (Corchorus olitorius) leaves. Food Chem Toxicol. 2013;55:78-91.

31. Patel BM, Raghunathan S, Porwal U. Cardioprotective effects of magnesium valproate in type 2 diabetes mellitus. Eur J Pharmacol. 2014;728:128-34.

32. Tsuneki H, Tokai E, Suzuki T, Seki T, Okubo K. Protective effects of coenzyme Q10 against angiotensin II-induced oxidative stress in human umbilical vein endothelial cells. Eur J Pharmacol. 2013;701:218-27.

33. Das AK, Sahu R, Dua TK, Bag S, Gangopadhyay M, Sinha MK. Arsenic-induced myocardial injury: protective role of Corchorus olitorius leaves. Food Chem Toxicol. 2010;48:1210-7

34. Rashid K, Das J, Sil PC. Taurine ameliorate alloxan induced oxidative stress and intrinsic apoptotic pathway in the hepatic tissue of diabetic rats. Food Chem Toxicol. 2013;51:317-29.

35. Wu B, Lin R, Dai R, Chen C, Wu H. Valsartan attenuates oxidative stress and NF-KB activation and reduces myocardial apoptosis after ischemia and reperfusion. Eur J Pharmacol. 2013;705:140-7.

36. Nelson TJ, Sun MK, Hongpaisan J, Alkon DL. Insulin, PKC signaling pathways and synaptic remodeling during memory storage and neuronal repair. Eur J Pharmacol. 2008;585:76-87

37. Geraldes P, King GL. Activation of protein kinase $\mathrm{c}$ isoforms and its impact on diabetic complications. Circulation Res. 2010;106:1319-31.

38. Liu H, Yang H, Wang D, Liu Y, Liu X. Insulin regulates P- glycoprotein in rat brain microvessel endothelial cells via an insulin receptor-mediated PKC/NF-KB pathway but not a PI3K/Akt pathway. Eur J Pharmacol. 2009;602:277-82.

39. Meier M, Menne J, Park JK, Haller H. Nailing down PKC isoform specificity in diabetic nephropathy - two's company, three's a crowd. Nephrol Dial Transplant. 2007;22:2421-5.

40. Su J, Zou W, Cai W, Chen X, Wang F. Atorvastatin ameliorates contrast medium-induced renal tubular cell apoptosis in diabetic rats via suppression of Rho-kinase pathway. Eur J Pharmacol. 2014;723:15-22.

41. Snel M, van Diepen JA, Stijnen Y, Pij H, Romijn JA. Immediate and long-term effects of addition of exercise to a 16-week very low calorie diet on low-grade inflammation in obese, insulin-dependent type 2 diabetic patients. Food Chem Toxicol. 2011;49:3104-11.

42. Arya A, Cheah SC, Looi CY, Taha H, Mustafa MR. The methanolic fraction of Centratherum anthelminticum seed downregulates pro-inflammatory cytokines, oxidative stress, and hyperglycemia in STZ-nicotinamide-induced type 2 diabetic rats. Food Chem Toxicol. 2012:50:4209-20.

43. Sangeetha KN, Sujatha S, Muthusamy VS, Anand S, Nithya N. 3ß-taraxerol of Mangifera indica, a PI3K dependent dual activator of glucose transport and glycogen synthesis in 3 T3-L1 adipocytes. Biochim Biophys Acta. 1800;2010:359-66.

44. Sangeetha KN, Shilpa K, Jyothi Kumari P, Lakshmi BS. Reversal of dexamethasone induced insulin resistance in 3T3L1 adipocytes by 3ß-taraxerol of Mangifera indica. Phytomed. 2013;20:213-20.

45. Yao X, Li G, Bai Q, Xu H. Taraxerol inhibits LPS-induced inflammatory responses through suppression of TAK1 and Akt activation. Int Immunopharmacol. 2013;15:316-24.

46. Halim EM. Lowering of blood sugar by water extract of Azadirachta indica and Abroma augusta in diabetes rats. Indian J Exp Biol. 2003;41:636-40.

\section{Submit your next manuscript to BioMed Central and take full advantage of:}

- Convenient online submission

- Thorough peer review

- No space constraints or color figure charges

- Immediate publication on acceptance

- Inclusion in PubMed, CAS, Scopus and Google Scholar

- Research which is freely available for redistribution 